\title{
Perceived Service Quality and Customer Satisfaction - Employees' Perspectives of Kenyan Private Universities
}

\section{Eric Mang'unyi Krishna Govender}

\begin{abstract}
This paper reports on an empirical study conducted among a sample 133 employees of private higher education institution in Kenya, to examine the relationship between perceived service quality (SQ) and customer satisfaction (CS), using the HEdPERF instrument. Although service quality was measured using six dimensions namely: academic, non-academic, reputation, access, programmes and understanding, by using structural equation modelling (SEM), the six SQ dimensions needed to be collapsed into four, since these were significant to the employees of private universities. The employee is viewed as a 'customer' of the private higher education institution, thus service quality refers to the employee-customers' perceptions. The results partially support the proposed conceptual model that non-academic, access, academic and reputation dimensions have a positive and significant influence on the employees' SQ perceptions, and in turn influences their satisfaction. It can be inferred from the findings that university quality should not only be looked at in terms of academic activities alone, as non-academic aspects also need to be considered since they are deemed important to the employees. Since universities are in both national and international competition, they (management) should aim at ensuring that all services related to organizational life like physical, implicit and explicit are delivered to acceptable standards to realize increased satisfaction.
\end{abstract}

Keywords: Private higher education; service quality; employee satisfaction, HEdPERF 


\section{Introduction}

In most service organizations, every effort is made to increase service quality and satisfy customers and therefore increase the overall organizational performance. The literature on the marketing of services illustrates that service quality is a precursor to customer satisfaction (Hensley \& Sulek 2007; Herrington \& Weaven 2007; Hishamuddin \& Azleen 2008; Siddiqi 2011), builds loyalty (Chitty \& Soutar 2004; Govender \& Ramroop 2012; Jones \& Sasser 1995) and enhances retention (Martensen et al. 2000).

Private universities have been acknowledged to attract 'employeecustomers' due to strategies such as retention of skilled human capital (Materu 2007) and unique experience, which has led to a reduction in professional emigration or what is referred to as the brain drain (Odhiambo 2011). Another factor that attracts 'employee-customers' is that private universities are often associated with quality (Materu 2007), which most individuals want to align with. In spite of the aforementioned, with increased global competition, quality of the service may play a bigger role in dictating employee commitment and satisfaction.

Although the literature on service quality and customer satisfaction issues in the context of the higher education sector is ever-increasing (Alaba \& Olanrewaju 2012; Calvo-PorallLevy-Mangin \& Novo-Corti 2013; De Jager \& Gbadamosi 2010; Govender \& Ramroop 2012; Hasan \& Ilias 2008; Hishamuddin \& Azleen 2008; Khodayari \& Khodayari 2011; Trivellas \& Dargenidou 2009; Yunus, Ismail, Ishak \& Juga 2009), little research pertains to the employees (as customers) of private HEIs, with respect to their service quality perceptions and satisfaction with the service. In order to address the aforementioned, this paper presents results of an exploratory empirical study to determine the relationship between service quality (SQ) and satisfaction (CS) among academic and administrative staff in Kenyan private universities.

\section{Brief Literature Review}

Zeithaml and Bitner (1996) define service quality as the delivery of exceptional service relative to customer expectations, whereas Gronroos (2000) regards service quality as a process consisting of a series of intangible activities that normally happen during interactions between the customer and service employees. Fogli (2006) views service quality as a positive or negative global attitude relating to a particular service. In higher education institutions (HEIs) 
however, some researchers (Rasli, Danjuma, Yew \& Igbal 2011) associate experience and the level of satisfaction gained by university customers with their service encounters as an indicator of service quality. Quinn, Lemay, Larson and Johnson (2009) define service quality in higher education in terms of educational, administration and supporting services. Although some researchers, inter-alia, (Gronroos 2000) view services as an integral part of services marketing others (Wisniewski 2001), argue that the complexity of both defining and measuring service quality, is one reason that has raised a lot of interest on the subject. In this paper, the researchers define perceived service quality as the ability of a particular service to gratify the anticipated needs of a customer.

\section{The HE Employee as a Customer}

Mudie and Pirrie (2006) argue that the characteristics exhibited by higher education (HE) services, namely, intangibility, inseparability, heterogeneity and perishability, are no different from those associated with other services. However, while HE possesses the traditional characteristics of a service offering, the unique characteristics are notable which differentiate it from any other retail service. One such characteristic is the conflicting views on the customer, since various stakeholders inter alia, employees, students, parents, sponsors, and the government utilize the services of HE (Quinn et al. 2009). Each of the aforesaid customers has access to a HE offering. Students are possibly as the first and most obvious customers because they pay for the education service, as well as need to prove their eligibility to enjoy the service. Sometimes, the cost of education is met by their parents or guardians and these individuals act as a point of contact for some service interactions with the higher education institution (HEI).

Similarly, employees (academic \& administrative), exercise control in the design of some of the services, and therefore also make use of a number of the HEI's services (Quinn et al. 2009:141). Singh (2000) stresses the significance of the service employee in service acts and service quality. There are also other stakeholders in HE who function as customers although for the different interests they have in the higher education process.

Whereas residence halls exclusively serve student-customers' accommodation needs, administrative areas in a university have explicit internal and external customers. For example, a research function or office 
serves internal staff and graduate students as well as government agencies and research sponsors (Quinn et al. 2009). The involvement of different stakeholders within the $\mathrm{HE}$ environment makes the measurement of $\mathrm{HE}$ services complicated compared to retail services, including how each stakeholder perceives the indicators of service which may also be conflicting (Becket \& Brookes 2006; Quinn et al. 2009). In view of the above mentioned, this research examines employees' as internal customers of HE with the objective of exploring their perception of service quality, and service satisfaction. The perceived experiences of the employees are important since, it may provide more objective and practical information for assessing making service quality and customer satisfaction in the HE context.

\section{Service Quality and Employee Satisfaction}

Some researchers (Parasuraman, Ziethaml \& Berry 1988) have postulated that a relationship exists between service quality and satisfaction. Furthermore, Hamand and Hayduk (2003) established that the SERVQUAL dimensions (Reliability, Responsiveness, Empathy, Assurance and Tangibility) had a positive relationship with satisfaction, and Reliability had the strongest relationship. Having investigated the importance of CS, SQ and service performance in a Taiwan library, Wang and Shieh (2006) also was found that some (Tangibles, Reliability, Assurance and Empathy) of the SERVQUAL dimensions also had a significant positive effect on the overall satisfaction of customer. Hasan and Ilias (2008) also assert that Empathy and Assurance were critical factors that contributed most to satisfaction. Parasuraman et al. (1988) argue that Reliability and Assurance have a direct relationship with the competence of an employee. Marx and Erasmus (2006) are of the view that processes and personnel are also crucial to service quality and enhance loyalty.

Petzer and Meyer (2011) found clear relationships between SQ, service satisfaction and behavioural intent, implying that customers' intention towards a service is dependent on previous experiences with the service delivery process. This eventually results in increased customer satisfaction (Basher, Machal \& Mwinyi 2012). In higher learning environments, employee expectations of a university depend on their experiences and individual preferences (De Jager and Gbadamosi 2010), and this therefore determines employees' decision-making process for example, for maximum commitment.

In many cases, employees working in higher education institutions are 
normally found in two environments, namely, academic where staff is concerned mainly with the teaching and research components of academic activities, and administrative, which is generally characterized by support activities offered by administrative staff to the academic functions. Employees in service organizations have been widely acknowledged for organizational efficiency, considering their responsiveness and understanding (Parasuraman et al. 1988), allegiance (Farber \& Wycoff 1991), satisfaction (Voss et al. 2005), contact (Soteriou \& Chase 1998), motivation (Hays \& Hill 2001) and competence (Parasuraman et al. 1988).

In light of the above, the objective of this research was to determine the employees' (in Kenyan private universities) perceptions of service quality using the HEdPERF instrument, as well as to ascertain the relationship between their service equality and satisfaction.

\section{HEdPERF and Service Quality Measurement}

Although in the services literature, service quality has been widely researched, albeit primarily in a business context, the education sector has not been completely left, because education itself falls within the aegis of service industry. By citing Hill (1995), De Jager and Gbadamosi (2010: 253) assert that service provision and customer satisfaction in the education sector rely on individual employee and student interfaces (encounters), which lead to a highly diverse service quality experience due to the extensive nature of the service work. A great deal of debate on service quality and performance measurement has been biased towards 'gap' analysis (Cronin \& Taylor 1994), and that much of the enduring debate on the subject has been in favour of application of the 'gap' measures.

However, in recent years, performance-based measures have also increased in popularity (cf. Babakus \& Mangold 1992, as cited by Cronin \& Taylor 1994: 126).

Some researches (Sunanto, Taufiquarrahman \& Pangemanan 2007; Rajasekhar, Muninarayanappa \& Reddy 2009; Shekarchizadeh, Rasli \& HonTat, 2011) have shown extended use of the SERVQUAL instrument. However, despite its application in higher education, it has not gone without criticism (Alridge \& Rowley 1998), for example that the instrument merely captures a snapshot of perceptions at one point in time, and the repeatability of some questions. However, with minimum alterations, the SERVQUAL instrument 
can still be successfully applied in higher education (Hair 2006: 11).

Recognizing the difficulties associated with using the SERVQUAL instrument to measure service quality in the higher education environment, Firdaus (2005) presented six sub-dimensions of service quality, and conceptualized the HEdPERF model, which has increased in use in the last decade as measure for service quality in the context of HE. Firdaus (2006) modified the HEdPERF instrument to a six-factor structure with 41 items, since it was argued that HE has clear and distinct dimensions, namely; academic aspects, reputation, non-academic aspects, access, program issues and understanding. Although some researchers, inter-alia, Kimani (2011) have demonstrated its validity and reliability in a Kenyan population, there is still room for improving the HEdPERF instrument.

Several studies based on SQ and customer satisfaction (Firdaus 2006; Kimani 2011; Khodayari \& Khodayari 2011; Govender \& Ramroop 2012; Calvo-Porall et al. 2013) employed different instruments, and virtually few have applied the HEdPERF dimensions in higher education environments. Firdaus's $(2005 ; 2006)$ factor analysis approach identified SQ dimensions and existing associations between quality and satisfaction, and among the quality constructs. Kimani's (2011) correlation method with six HEdPERF SQ construct measurements resulted in the realization that a positive perception of service quality by the students in Kenyan universities impacts their overall satisfaction.

In the current study, six sub-dimensions of HEdPERF were used as determinants of SQ, and each dimension was hypothesized to have a positive relationship with service quality. In other words, these sub-dimensions were hypothesized to have greater levels of association and influence on customer satisfaction.

The literature, for example Parasuraman et al. (1988) has shown that in service organizations, employees' perceived SQ among other related factors, are important determinants of excellence of the service organizations. This paper strives to bring to the fore an understanding of the service institutions' dynamics, by investigating the inter-relationships among the HEdPERF perceived SQ dimensions (academic, non-academic, programme, reputation, access, and understanding), and customer satisfaction via employee perspectives as illustrated in the following conceptual research framework (Figure 1). The development of the relevant hypotheses will be explained in the next section. 


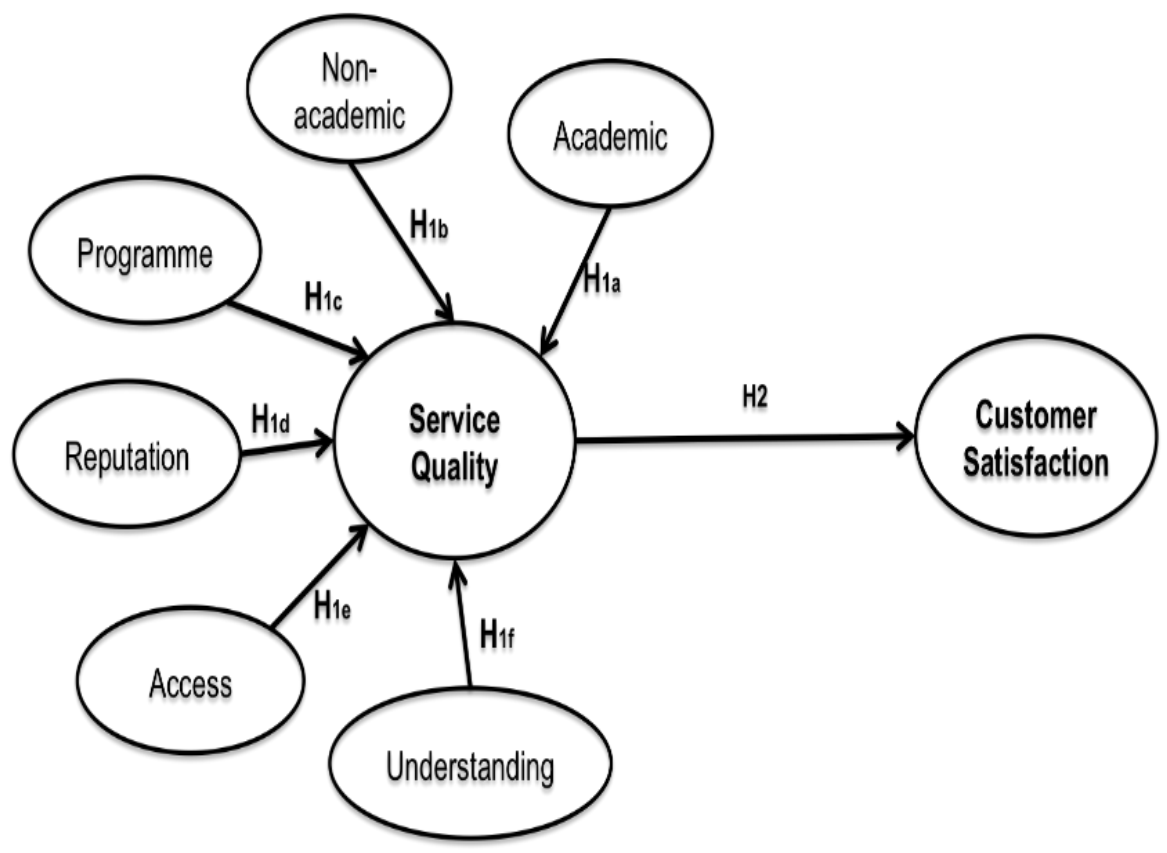

Figure 1: The Conceptual Framework

The value of the academic characteristics has been identified in most service quality studies conducted in higher education (De Jager \& Gbadamosi 2010; Kimani 2011; Govender \& Ramroop 2011). Access was considered most important in higher education by Kimani (2011). The importance of understanding the needs was highlighted by several researcher, namely, Watsch (2003); Chitty and Soutar, 2004; Deshields et al. 2005; Adela, 2009. Reputation has also been identified as another valuable aspect in the higher education sector to enhance retention (Martensen et al. 2000), and to build loyalty (Chitty \& Soutar 2004). The 'non-academic' aspects of the HE industry have also been recognised to influence employee obligation. For example, De Jager and Gbadamosi (2010) and Kimani (2011) outlined that it is important to make available facilities vis-à-vis trust and support from administration. Furthermore, academic programmes which are the 'products' offered by a higher education institution have been considered an important dimension 
(Firdaus 2006; Kimani 2011). Based on the aforementioned arguments, the literature provides a foundation to hypothesize that relationships exist between HEdPERF SQ and the aforementioned dimensions in private higher education in Kenya. Thus, we hypothesize as follows:

H1: The HEdPERF service equality constructs (academic aspects, non-academic aspects, programme aspects, reputation, access and understanding) influence the private higher education institutions employees' perception of the overall service quality.

Flowing from H1, the following sub-hypotheses are formulated with respect to private higher education employees:

- Hla: There is a positive relationship between academic activities and service quality.

- Hlb: There is a positive relationship between non-academic activities and service quality.

- HIc: There is a positive relationship between academic programmes and service quality.

- Hld: There is a positive relationship between reputation and service quality.

- Hle: There is a positive relationship between access and service quality.

- Hlf: There is a positive relationship between understanding and service quality.

Several studies (Hensley \& Sulek 2007; Herrington \& Weaven 2007; Hishamuddin \& Azleen 2008) in the higher education sector that have examined the association between service quality and satisfaction, have shown that service quality is a precursor of customer satisfaction. Positive word-ofmouth communication by satisfied customers may attract new customers, who may in turn spread the positive word to other people by word-of-mouth (Athiyaman 2007; Prugsamatz et al. 2006). High levels of service quality are related to increased customer satisfaction and thus lead to loyalty (Jones \& Sasser 1995), and retention (DeShields et al. 2005). Furthermore, there will be continuous patronage as long as quality remains an integral tool for service delivery at university (Rasli et al. 2011). Since the perceived SQ has a strong influence on $\mathrm{CS}$, it is therefore proposed $(\mathrm{H} 2)$ that there is a positive 
association between the private university employees' perceived service quality and their satisfaction.

\section{Method}

The study's target population was all academic and administrative employees of select private universities in Kenya. Through a cross-sectional survey, the sample target for the study was determined as 250 academic and administrative employees from four different private universities. The four universities were selected based on geographical location and ownership thus faith-based and 'commercial' categories and were included using a stratified purposeful random sampling technique. A pre-defined sample size calculator proposed by Krejcie and Morgan (1970), in (Sekaran 2006: 293) was used to obtain the sample size. Within each stratum, simple random sampling was implemented to select participants in the survey from the academic and administrative strata. To participate in the study, the employees had to be full-time members of either academic or administrative category in their respective institutions. Thereafter, samples were selected considering respective divisions and or sections they worked in.

A 7- point Likert scale, where $1=$ strongly disagree and $7=$ strongly agree, was used to measure the SQ dimensions, general SQ, and satisfaction. The scales used were developed around:

- 'Non-academic aspects' which looked at the functions performed by administrative staff which are essential to enable students to fulfill their study obligations;

- 'Academic aspects' represented factors related to the responsibilities of academics and or teaching faculty;

- 'Reputation' referred to the ability of higher learning institutions to project a professional image;

- 'Access' referred to issues inter-alia, approachability, ease of contact, availability and convenience;

- 'Programme issues' looked at the importance of offering wide ranging and reputable academic courses and or specializations, with flexible structure and syllabi; 
- 'Understanding' measured issues relating to knowing students' specific needs in terms of counselling and health services;

- 'General quality' determined opinions about the general service quality; and

- 'General satisfaction' aimed to understand the satisfaction the ememployee derived from their service responsibilities and duties, their colleagues and their institutions.

The researchers explained the intention of the study and the research procedure to the employees of the sampled institutions. Two hundred and fifty questionnaires were distributed to both academic and administrative employees of the four universities, in equal proportion per university in late September 2013 to January 2014. Furthermore participants voluntarily completed the questionnaire at their places of employment, at their own time and these were collected or dropped off at designated areas as agreed with the researcher. A standard protocol for administering the questionnaire was used either by the researcher or a trained research assistant. Absolute confidentiality of the responses was guaranteed and upheld.

The researchers used SPSS AMOS 21 to conduct exploratory factor analysis (EFA), structural equation modelling (SEM) test the hypotheses, since Schumacker and Lomax (2004) asserted that SEM is clear and testable, and competing models can be analysed, synthesized and understood and, their effect whether direct, indirect or both can be investigated.

\section{Research Results}

Of the 250 questionnaires administered, 133 were usable, which represents are response rate, which exceeds 50\%. Table 1 shows that the majority (59.4\%) of the employees (respondents) were in administrative positions, and academics comprised $40.6 \%$ of the sample, and of these, $54.9 \%$ were male and female comprised the rest. With regard to age of the respondents, the majority $(47.4 \%$ ), were middle aged (30 to 39 years) or younger, $31.6 \%$ were aged between 40 to 49 years, and $19.5 \%$ were below 30 years. The vast majority (78.9\%) had been employed for up to 10 years in their respective institutions, and $27.8 \%$ of academic staff (respondents) had PhDs. In terms of positions, $42.1 \%$ were middle managers, $9.8 \%$ technical posts, and $6.8 \%$ senior managers. 
Employees' Perspectives of Kenyan Private Universities

\begin{tabular}{|c|c|c|c|}
\hline Variable & Value label & Frequency & $\begin{array}{l}\text { Valid Percent } \\
(\%)\end{array}$ \\
\hline $\begin{array}{l}\text { Education } \\
\text { Qualification }\end{array}$ & $\begin{array}{l}\text { Diploma } \\
\text { Bachelor's Degree } \\
\text { Masters Degree } \\
\text { PhD (on-going) } \\
\text { PhD }\end{array}$ & $\begin{array}{l}18 \\
39 \\
38 \\
23 \\
15\end{array}$ & $\begin{array}{l}13.5 \\
29.3 \\
28.6 \\
17.3 \\
11.3\end{array}$ \\
\hline Gender & $\begin{array}{l}\text { Male } \\
\text { Female }\end{array}$ & $\begin{array}{l}73 \\
59\end{array}$ & $\begin{array}{l}54.9 \\
44.4\end{array}$ \\
\hline $\begin{array}{l}\text { Occupational } \\
\text { Groups }\end{array}$ & $\begin{array}{l}\text { Academic } \\
\text { Administrative }\end{array}$ & $\begin{array}{l}54 \\
79\end{array}$ & $\begin{array}{l}40.6 \\
59.4\end{array}$ \\
\hline Age Group & $\begin{array}{l}<30 \text { years } \\
30-39 \\
40-49 \\
>50\end{array}$ & $\begin{array}{l}26 \\
63 \\
42 \\
1\end{array}$ & $\begin{array}{l}19.5 \\
47.4 \\
31.6 \\
.8\end{array}$ \\
\hline $\begin{array}{l}\text { University Service } \\
\text { Experience }\end{array}$ & $\begin{array}{l}0-4 \text { years } \\
5-10 \text { years } \\
11-15 \text { years } \\
16+\text { years }\end{array}$ & $\begin{array}{l}54 \\
51 \\
19 \\
8\end{array}$ & $\begin{array}{l}40.6 \\
38.3 \\
14.3 \\
6.0\end{array}$ \\
\hline $\begin{array}{l}\text { Management } \\
\text { Level of Non- } \\
\text { teaching staff }\end{array}$ & $\begin{array}{l}\text { Senior } \\
\text { management } \\
\text { Middle } \\
\text { management } \\
\text { Technical staff } \\
\text { No Response }\end{array}$ & $\begin{array}{l}9 \\
56 \\
13 \\
55\end{array}$ & $\begin{array}{l}6.8 \\
42.1 \\
9.8 \\
41.4\end{array}$ \\
\hline
\end{tabular}

\section{Table 1: Socio-Demographic Characteristics of Employee Sample}

The Cronbach coefficient alphas were calculated using Stepwise Reliability Analysis, and Cronbach alpha values greater than 0.7 were accepted as reliable measures of internal consistency (Sekaran \& Bougie 2010: 325). Table 2 below, which summarizes the outcome of stepwise reliability analysis, shows that the scales are fairly reliable since all the Cronbach alphas exceeded 0.7 . 
Eric Mang’unyi \& Krishna Govender

\begin{tabular}{|l|l|l|}
\hline Instrument & $\begin{array}{l}\text { Final Number of } \\
\text { items }\end{array}$ & $\begin{array}{l}\text { Final Cronbach Alpha } \\
\text { coefficients }\end{array}$ \\
\hline $\begin{array}{l}\text { Non-Academic } \\
\text { Aspects }\end{array}$ & 18 & 0.758 \\
\hline Academic Aspects & 13 & 0.763 \\
\hline Reputation & 10 & 0.870 \\
\hline Access & 11 & 0.853 \\
\hline Programmes & 4 & 0.817 \\
\hline Understanding & 3 & 0.807 \\
\hline Overall satisfaction & 7 & 0.819 \\
\hline
\end{tabular}

\section{Table 2: Instrument Reliability}

Construct and discriminant validity were determined through Exploratory Factor Analysis (EFA) using the Principal Component Analysis with oblique rotation (Browne 2001). The results of the validity measures are as illustrated in Table 3.

\begin{tabular}{|c|c|c|c|c|c|}
\hline & 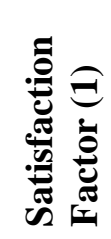 & 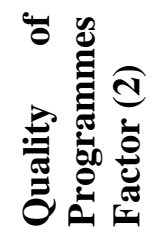 & 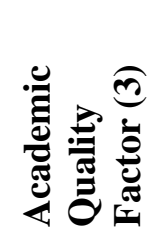 & 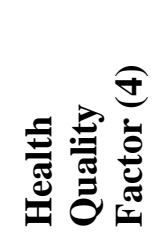 & 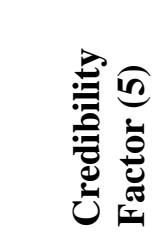 \\
\hline NOACD1 & .607 & .040 & .124 & -.073 & .002 \\
\hline NOACD2 & .387 & .345 & .154 & .503 & -.134 \\
\hline NOACD3 & .727 & .015 & .113 & .192 & -.123 \\
\hline NOACD4 & $.844 *$ & .103 & .234 & .163 & -.031 \\
\hline ACD1 & .131 & .171 & .786 & .026 & .134 \\
\hline ACD2 & .206 & .061 & .652 & -.091 & .243 \\
\hline ACD3 & -.095 & -.135 & .739 & .175 & -.222 \\
\hline ACD4 & .269 & .045 & $.823 *$ & .042 & -.013 \\
\hline REP1 & .758 & .235 & .191 & .192 & .121 \\
\hline REP2 & .662 & .468 & .172 & .050 & .060 \\
\hline $\mathrm{ACC1}$ & .794 & .119 & -.081 & .264 & .065 \\
\hline
\end{tabular}




\begin{tabular}{|c|c|c|c|c|c|}
\hline & 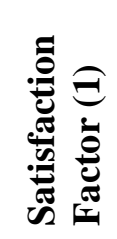 & 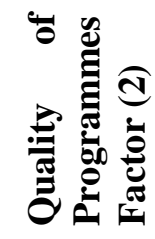 & لَّ & 至总总 & 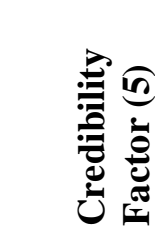 \\
\hline $\mathrm{ACC} 2$ & .678 & .157 & .229 & .388 & -.016 \\
\hline ACC3 & .668 & .372 & .065 & .238 & .151 \\
\hline SAT1 & .544 & .422 & -.014 & .158 & .066 \\
\hline SAT2 & .755 & .210 & .017 & .155 & .292 \\
\hline PROG1 & .364 & .714 & .050 & .166 & -.151 \\
\hline PROG2 & .414 & .657 & -.015 & .138 & .162 \\
\hline PROG3 & .047 & $.831 *$ & .006 & .182 & .008 \\
\hline PROG4 & .055 & .769 & .095 & .230 & .021 \\
\hline QUALGEN & .080 & -.010 & .097 & .172 & $.873 *$ \\
\hline UND1 & .169 & .371 & .014 & $.813 *$ & .091 \\
\hline UND2 & .230 & .280 & -.042 & .778 & .131 \\
\hline UND3 & .474 & .056 & .180 & .567 & .230 \\
\hline
\end{tabular}

Table 3: Rotated Factor Loadings for Employee Measurements *Highest factor loadings

Note: $\mathrm{NOACD}=$ non-academic, $\mathrm{ACD}=$ academic, $\mathrm{REP}=$ reputation, $\mathrm{ACC}=$ access, $\mathrm{PRG}=$ programme, $\mathrm{UND}=$ understanding, $\mathrm{SAT}=$ Satisfaction, OvrQual = overall quality, QUALGEN = quality general.

From Table 3 above, it is evident that the data loaded onto five factors with factor loadings exceeding 0.4 , which were appropriately labeled as follows: Factor 1 - Satisfaction, Factor 2 - Quality of Academic Programmes, Factor 3 - Academic Quality, Factor 4 - Health Quality, and Factor 5 Credibility. Since the factors loadings exceeding 0.4 it is apparent that the items in the research instrument are ideal measures of validity (Hair et al. 2006).

The conceptual research model illustrated in Figure 1 was tested using AMOS 21 to explore the hypothesized relationships. The model was found to be adequate and this was confirmed by the chi-square value (85.448, degrees of freedom $=82)$, and its corresponding $\mathrm{p}$-value $(0.375)$. Comparing the $\mathrm{p}$ - 
value with level of significance of 0.05 , the $p$-value was greater than 0.05 hence, the model was declared adequate since values of p-value, exceeding 0.05 (Hair et al. 2006). Furthermore, the structural equation modelling was conducted and evaluated on the basis of goodness of fit indices which are reflected in Table 4, inter alia, the comparative fit index (CFI), root mean square error of approximation (RMSEA) and the ratio of Chi-square value to the degrees of freedom (CMIN/DF) ratio (Browne \& Cudeck, 1993). The CFI value exceeded 0.95, which showed the model fitted the data well. Furthermore, the small RMSEA values, particularly less than 0.04, also indicate that the model fitted the data well (Hair et al. 2006), and the CMIN/DF values, which are less than 3 show a better model fit (Schumacker \& Lomax 2004). With regard to incremental fit measures, namely, the normed fit index (NFI), relative fit index (RFI), incremental fit index (IFI) and Tucker-Lewis index (TLI), where all values exceeded 0.90 , further confirming that the model fitted the data well (Hair et al. 2006; Hu and Bentler, 1999). In conclusion, the $\mathrm{CFI}=0.997, \mathrm{CMIN} / \mathrm{DF}=1.042$ and $\mathrm{RMSEA}=0.018$, as shown in the Table 4 below, indicate that the model fitted the data well, thus, the suitability of the proposed employee service quality model

\begin{tabular}{|l|l|l|l|}
\hline Fit Index & Acronym & Value & Desired range \\
\hline Absolute Fit Measures & $X^{2}$ & $\begin{array}{l}85.448 \\
(\mathrm{p}=.375)\end{array}$ & $\begin{array}{l}\text { P>.05 (non- } \\
\text { significant) }\end{array}$ \\
\hline Chi-square test (CMIN) & $D f$ & 82 & $\geq 0$ \\
\hline Degrees of freedom & $X^{2} / d f$ \\
$($ CMIN/DF) & 1.042 & 2 to 3 \\
\hline $\begin{array}{l}\text { Ratio of Chi-square/degrees } \\
\text { of freedom }\end{array}$ & RMSEA & .018 & $<.04$ \\
\hline $\begin{array}{l}\text { Root mean square error of } \\
\text { approximation }\end{array}$ & NFI & .924 & $>.90$ \\
\hline Incremental/Relative Fit Measures & .903 & $>.90$ \\
\hline Normed Fit Index & RFI & .997 & $>.90$ \\
\hline Relative Fit Index & IFI & .996 & $>.90$ to >.95 \\
\hline Incremental Fit Index & TLI & $\mathbf{. 9 9 7}$ & $>.90$ \\
\hline Tucker-Lewis Index & CFI & \\
\hline Comparative Fit Index & Rom & \\
\hline
\end{tabular}

Table 4: Goodness-of-fit Indices for the Employee Structural Model

Source: Hair et al. 2006; Hu \& Bentler, 1999; Schumacker \& Lomax, 2004. 


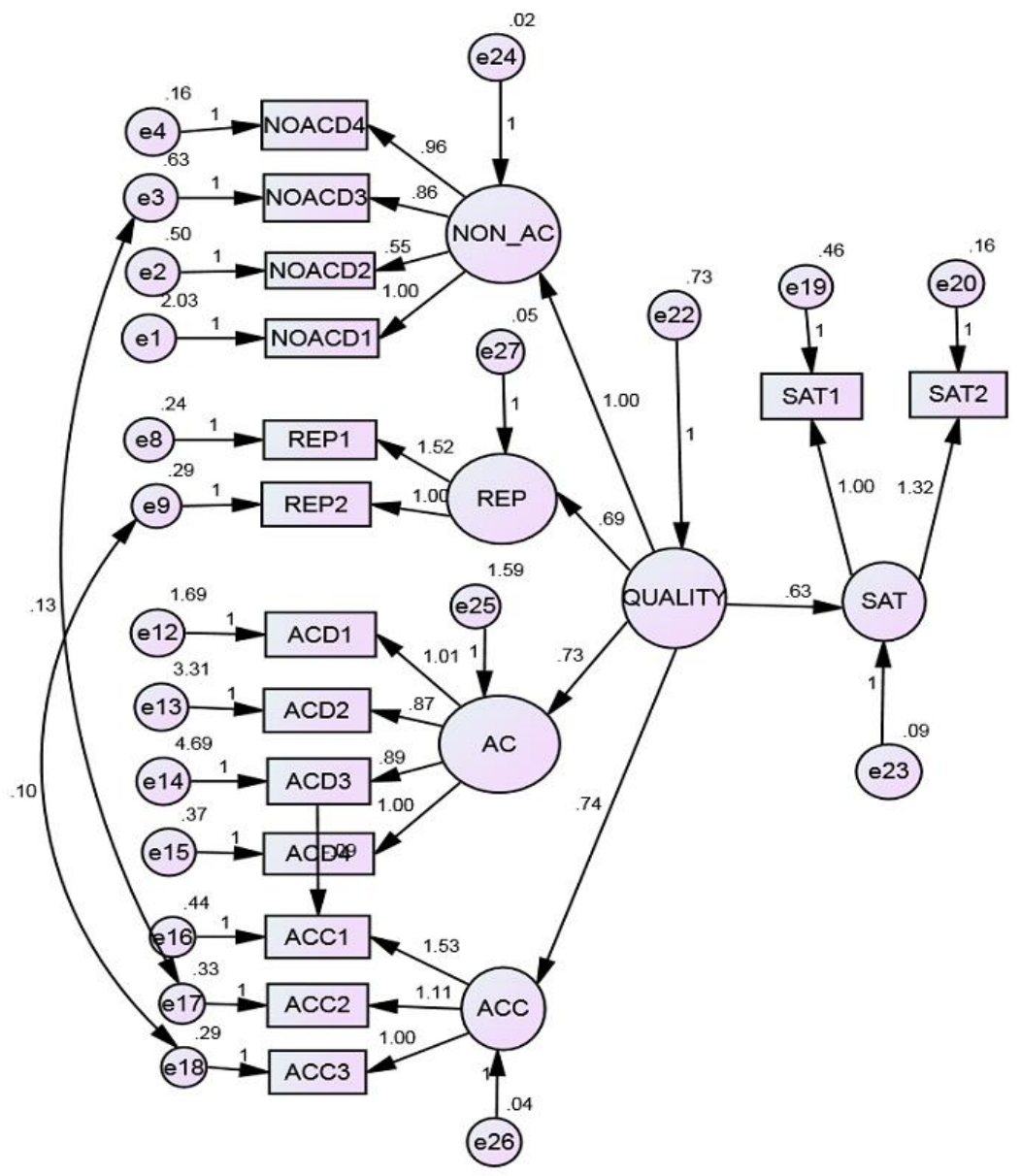

Minimum was achieved

Chi-square $=85.448$

Degrees of freedom $=82$

$P$-value $=0.375$

Figure 2: Employee-Customer - Service Quality Hypothesized Model and the Standardized Loadings 
To test the research hypotheses and investigate the relationship between perceived university SQ and employee satisfaction, we conducted covariance analysis. Figure 2, above, shows the structural model between university service quality and employee perceived quality with the resulting maximum likelihood standardized estimators. The model illustrates that some HEdPERF SQ dimensions (non-academic, reputation, academic, access) impact employee perceived SQ, and consequently influence employee satisfaction. Figure 2 represents an exhaustive reporting of results of various hypotheses postulated by way of a (snapshot) path diagram. The decisions on the various hypotheses are explained in the next section.

Causal path properties and standardized coefficients are illustrated in Figures $2 / 3$, while the significance of the standardized coefficients and the critical ratios (CR) for the hypotheses are shown in Table 4 . The acceptable $\mathrm{p}$ value limit is 0.0001 .

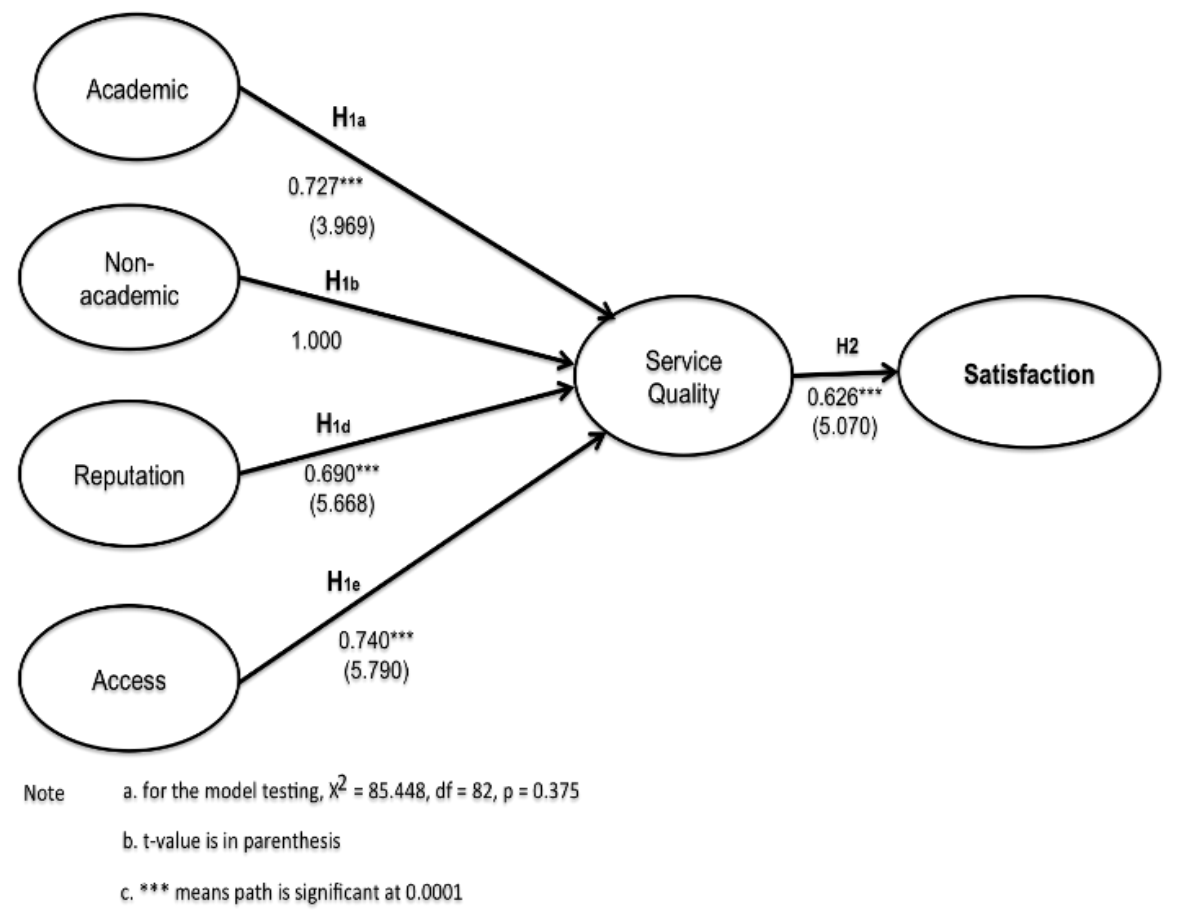

Figure 3: Path Coefficients of the Structural Equation 
According to Figure 3, not all of the HEdPERF SQ variables were associated with the employees' perception of the private universities' service quality. Thus, the main hypothesis (H1) is partially supported through the academic, non-academic, reputation and access dimensions. With regard to the secondary hypotheses, only $\mathrm{Hla}, \mathrm{Hl}$, Hld and Hle are also supported, which imply that academic activities, non-academic activities, reputation and access, respectively would be positively related to the perceived service quality. Thus it was observed that similar to previous empirical studies (Firdaus 2006; Owlia \& Aspinwall 1996; Parasuraman et al. 1985), issues like access (inter alia ease of contact, availability of both academic and administrative staff and convenience) contributes to higher perceived SQ from the employees' standpoint. The ability to project a professional image (reputation) was found to be important (De Jager \& Gbadamosi 2010; Gronroos 1984) in HE industry and it creates loyalty (Chitty \& Soutar 2004). Furthermore, the aforementioned results are positively related to Firdaus' (2006) determinants of SQ, where the academic and non-academic characteristics were found to be important quality indicators, and thus confirming the views of earlier researchers (Leblanc \& Nguyen, 1997; Soutar \& McNeil, 1996).

\begin{tabular}{|l|l|l|l|l|l|l|}
\hline \multicolumn{2}{|c|}{ Relationship } & Employee & $H 1 a(+)$ & .727 & .183 & $3.969 * * *$ \\
\hline quality & Academic & $\leftarrow$ & Fixed & Fixed \\
\hline $\begin{array}{l}\text { Non- } \\
\text { academic }\end{array}$ & $\leftarrow$ & $\begin{array}{l}\text { Employee } \\
\text { quality }\end{array}$ & $H 1 b(+)$ & 1.000 & Fin \\
\hline Access & $\leftarrow$ & $\begin{array}{l}\text { Employee } \\
\text { quality }\end{array}$ & $H 1 e(+)$ & .740 & .128 & $5.790 * * *$ \\
\hline Reputation & $\leftarrow$ & $\begin{array}{l}\text { Employee } \\
\text { quality }\end{array}$ & $H 1 d(+)$ & .690 & .122 & $5.668 * * *$ \\
\hline $\begin{array}{l}\text { Employee } \\
\text { Satisfaction }\end{array}$ & $\leftarrow$ & $\begin{array}{l}\text { Employee } \\
\text { quality }\end{array}$ & $H 2(+)$ & .626 & .124 & $5.070 * * *$ \\
\hline
\end{tabular}

Note: $* * *$ means $<0.0001$

Table 4: Model Parameter Estimation \& Levels of Statistical Significance 
The statistical results also confirm $\mathrm{H} 2$, in that the employees' perceived service quality is related to their satisfaction, since the path coefficient is $0.626(t=5.070 ; p<0.0001)$. Furthermore, the findings imply that when quality increases by one unit employee satisfaction increases by 0.626 . These findings, which supported hypothesis, are consistent with earlier studies (Zeithaml \& Bitner 1996; Ojo, 2010; Rasli, Danjuma, Yew \& Igbal 2011) supporting the proposition of a strong relationship between service quality and employee satisfaction. It became apparent that the rest of the HEdPERF quality items (programme and understanding) did not load onto the model, and were therefore dropped. Thus hypotheses HIb and Hld could not be confirmed through this study.

\section{Conclusions}

The empirical evidence implies that the SQ dimensions indirectly and or directly impact on customer satisfaction. The findings also reveal that with regard to the conceptual framework proposed by Firdaus (2006) and some other researchers, tested among a sample of employees of Kenyan private universities, only four HEdPERF variables namely, non-academic, access, reputation, and academic influenced the SQ and satisfaction. Notably, this study has provided a basis for further explorations to probe the nature and value of academic, non-academic, reputation and access dimensions as criteria that employees consider in evaluating their satisfaction with university services in a developing country context. Additionally, for more rigorous findings, it is recommended that future research using the HEdPERF tool focus on satisfaction level in SQ among different stakeholders for both public and private universities and across other cultural contexts.

The results of this study on 'employee-customer' satisfaction provide a rationale for the study, since it can help the university to improve service quality. Universities could also improve their SQ by increasing employee satisfaction through 'manipulation' of the abovementioned dimensions of the service provider since it has been acknowledged universally that SQ is an antecedent of satisfaction. Emphasizing these critical dimensions of SQ implies that the university will be making headway towards a better assessment of its quality and satisfaction. Furthermore, the findings will also help the university to better understand what dimensions have a greater influence on $\mathrm{SQ}$, and in turn influences employee satisfaction. This can be achieved through 
creating an enabling environment for the employees as service providers which will increase their satisfaction levels. By so doing, the employees will endeavour to delight and satisfy their internal customers (other employees) and external customers, which include students.

The findings have to be tempered by the fact this study was only conducted among respondents from four private universities. Future research may focus on a comparative study with government sponsored public universities to investigate whether there are significant differences in perceived service quality and employee satisfaction among private and public university staff.

\section{References}

Alaba, A.R. \& A.K. Olanrewaju 2012. Service Quality Dimensions and Thesis Writing among Postgraduate Students in Southwest Nigeria. Universal Journal of Education and General Studies 1, 7: 188 - 194.

Aldridge, S. \& J. Rowley 1998. Measuring Customer Satisfaction in Higher Education. Quality Assurance in Education 6, 4: 197 - 204. https://doi.org/10.1108/09684889810242182

Basher, M.S., M.M. Machali \& A.M. Mwinyi 2012. The Effect of Service Quality and Government Role on Customer Satisfaction. International Journal of Business and Social Science 3, 14: 312 - 319.

Becket, N. \& M. Brookes 2006. Evaluating Quality Management in University Departments. Quality Assurance in Education 14, 2: 123 - 142. https://doi.org/10.1108/09684880610662015

Calvo-Porall, C., J.P. Levy-Mangin \& I. Novo-Corti 2013. Perceived Quality in Higher Education: An Empirical Study. Marketing Intelligence and Planning 36, 6: 60.

Chitty, B. \& G.N. Soutar 2004. Is the European Customer Satisfaction Index Model Applicable to Tertiary Education? Marketing Accountabilities and Responsibilities. Wellington, N.A: Australian and New Zealand Marketing Academy Conference 2004.

Cronin, J.J. \& S.A. Taylor 1994. SERVPERF versus SERVQUAL: Reconciling Performance-Based Perception-Minus-Expectations Measurement of Service Quality. Journal of Marketing 58, 1: 125 - 131. https://doi.org/10.1177/002224299405800110 
https://doi.org/10.2307/1252256

De Jager J. \& G. Gbadamosi 2010. Specific Remedy for Specific Problem: Measuring Service Quality in South African Higher Education. Higher Education 60,3: 251 - 267.

https://doi.org/10.1007/s10734-009-9298-6

Farber, B. \& J. Wycoff 1991. Customer Service: Evolution and Revolution.

Sales and Marketing Management 44 - 51.

Firdaus, A. 2005. The Development of HEdPERF: A New Measuring Instrument of Service Quality for the Higher Education Sector. International Journal of Consumer Studies 30, 6: 569 - 581.

https://doi.org/10.1108/02634500610641543

Firdaus, A. 2006. Measuring Service Quality in Higher Education: HEdPERF versus SERVPERF. Marketing Intelligence \& Planning 24, 1: 31 - 47.

Fogli, L. 2006. Customer Service Delivery. San Francisco: Jossey-Bass.

Govender, K.K. \& S. Ramroop 2012. Relationship between the Postgraduate

Research Students' Perception of their Role, Research Climate and Service Quality. African Journal of Business Management 6, 4: 1642 1651.

Gronroos, C. 2000. Service Management and Marketing: A Customer Relationship Management Approach. $2^{\text {nd }}$ Edition. West Sussex: John Wiley \& Sons Ltd.

Hasan, H.F.A. \& A. Ilias 2008. Service Quality and Student Satisfaction: A Case Study at Private Higher Education Institutions. International Business Research 1, 3: 163 - 175.

Hays, J. \& A. Hill 2001. A Preliminary Investigation of the Relationships between Employees Motivation/Vision, Service Learning, and Perceived Service Quality. Journal of Operations Management 19, 3: 335 - 349. https://doi.org/10.1016/S0272-6963(00)00061-9

Hensley, R.I. \& J. Sulek 2007. Customer Satisfaction with Waits in Multi-

Stage Services. Managing Service Quality 17, 2: 152 - 173.

https://doi.org/10.1108/09604520710735173

Herrington, C. \& S. Weaven 2007. Can Banks Improve Customer Relationships with High Quality Online Service? Managing Service Quality 1, 4: 404 - 427.

https://doi.org/10.1108/09604520710760544

Hishamuddin, F.A.H. \& I. Azleen 2008. Service Quality and Student Satisfaction: A Case Study at Private Higher Education Institutions. 
International Business Research 1, 3: 163 - 175.

Khodayari, F. \& B. Khodayari 2011. Service Quality in Higher Education, Interdisciplinary Journal of Research in Business 1, 9: 38 - 46.

Kimani, W.S. 2011. Business Students' Perception of Service Quality in Kenyan Private and Public Universities. Nairobi: CUEA Press.

Malik, M.E., R.Q. Danish \& A. Usman 2010. The Impact of Service Quality on Students' Satisfaction on Higher Education Institutes of Punjab. Journal of Management Research 2, 2: 1 - 11.

Martensen, A., L. Gronhold, J.K. Eskildsen \& K. Kristensen 2000. Measuring Student Oriented Quality in Higher Education: Application of the ECSI Methodology. Sinergie Rapport di Ricercan 9: 372 - 383.

Materu, N.P. 2007. Higher Education Quality Assurance in Sub-Saharan Africa: Status, Challenges, Opportunities and Promising Practices. World Bank Working Paper No. 124.

https://doi.org/10.1596/978-0-8213-7272-2

Molapo, M.E. \& G. Mukwada 2011. The Impact of Customer Retention Strategies in the South African Cellular Industry: The Case of the Eastern Free State. International Journal of Business, Humanities and Technology 1, 2: $52-60$.

Mudie, P. \& A. Pirrie 2006. Services Marketing Management. $3^{\text {rd }}$ Edition. Oxford: Elsevier Ltd.

Parasuraman, A., L.L. Berry, \& V.A. Zeithaml 1988. SERVQUAL: A Multiple-Item Scale for Measuring Consumer Perceptions of Service Quality. Journal of Retailing 64, 1: 12 - 40.

Peter, D.J. \& C.F. Meyer 2011. The Perceived Service Quality, Satisfaction and Behavioural Intent towards Cell Phone Network Service Providers: A Generational Perspective. African Journal of Business Management 5, 17 : $7461-7473$.

https://doi.org/10.5897/AJBM11.302

Prugsamatz, S., R. Pentecost \& L. Ofstad 2006. The Influence of Explicit and Implicit Service Promises on Chinese Students' Expectations of Overseas Universities. Pacific Journal of Marketing and Logistics 18, 2: 129 - 145. https://doi.org/10.1108/13555850610658273

Quinn, A., G. Lemay, P. Larsen \& D.M. Johnson 2009. Service Quality in Higher Education. Total Quality Management 20, 2: 139 - 152.

https://doi.org/10.1080/14783360802622805

Rajasekhar M., M. Muninarayanappa \& S.V.S. Reddy 2009. The GAP Model 
Analysis of Service Quality in Indian Higher Education. Journal of Social Sciences 1, 2: 214 - 229.

Rasli, A., I. Danjuma, L.K. Yew \& M.J. Igbal 2011. Service Quality, Customer Satisfaction in Technology-Based Universities. African Journal of Business Management 5, 15: 6541 - 6553.

Sekaran, U. \& R. Bougie 2010. Research Methods for Business: A Skill Building Approach. $5^{\text {th }}$ Edition. New York: John Wiley \& Sons Inc.

Siddiqi, K.O. 2011. Interrelations between Service Quality Attributes, Customer Satisfaction and Customer Loyalty in the Retail Banking Sector in Bangladesh. International Journal of Business and Management 6,3: 12 - 36.

https://doi.org/10.5539/ijbm.v6n3p12

Singh, J. 2000. Performance Productivity and Quality of Frontline Employees in Service Organization. Journal of Marketing 64,15: 3 - 4.

https://doi.org/10.1509/jmkg.64.2.15.17998

Soteriou, A. \& R. Chase 1998. Linking the Customer Contact Model to Service Quality. Journal of Operations Management 16, 4: 495 - 508.

https://doi.org/10.1016/S0272-6963(98)00026-6

Sunanto S., T. Taufiquarrahman, R. Pangemanan 2007. An Analysis of University Services Quality Gap and Student Satisfaction in Indonesia. The International Journal of Know, Culand Change Management 7, 7: 1 $-10$.

Voss, C., N. Tsikriktsis, B. Funk, D. Yarrow \& J. Owen 2005. Managerial Choice and Performance in Service Management - A Comparison of Private Sector Organizations with Further Education Colleges. Journal of Operations Management 23, 2: 179 - 195.

https://doi.org/10.1016/j.jom.2004.07.005

Wang, I. \& C. Sheih 2006. The Relationship between Service Quality and

Customer Satisfaction: The Example of CJCU Library. Journal of Information and Optimization Sciences 27, 1: 193 - 201.

https://doi.org/10.1080/02522667.2006.10699686

Wisniewski, M. 2001. Using SERVQUAL To Assess Customer Satisfaction With Public Sector Services. Managing Service Quality 11, 6: 380 - 388. https://doi.org/10.1108/EUM0000000006279

Yunus, N.K.Y., A. Ismail, S. Ishak \& Z.R. Juga. 2009. Service Quality Dimensions, Perceive Value And Customer Satisfaction: ABC Relationship Model Testing. International Business and Economics 
Journal 2,1: 1 - 18.

Zeithaml, V.A., M.J. Bitner \& D.D. Grender 2006. Integrating Customer Focus across the Firm. $4^{\text {th }}$ Edition. New York: McGraw-Hill/ Irwin.

Eric E. Mang'unyi

School of Business

Department of Marketing and Management The Catholic University of Eastern AFrica

Nairobi, Kenya mangunyie@gmail.com

Krishna Govender

School of Management, IT and Governance, University of KwaZulu-Natal Durban, South Africa govenderkrishna@gmail.com 